\title{
Criminal Acts of Defamation in the Concept of Criminal Law
}

\author{
Mirawati Saktiana ${ }^{1}$, Megawati Barthos ${ }^{2}$ \\ \{mirawatisaktiana@gmail.com ${ }^{1}$, megawati_barthos@borobudur.ac.id² \\ Universitas Borobudur, Jakarta, Indonesia ${ }^{1,2}$
}

\begin{abstract}
This paper provides a study related to criminal acts of defamation in the concept of criminal law. By using normative juridical research methods and data collection using literature studies and analyzed descriptively to conclude. It was found that defamation was classified as a criminal act based on moral theory and based on the cultural values of the Indonesian people, as well as to protect the material and immaterial interests of the community.
\end{abstract}

Keywords: Reputation; Pollution; Criminal

\section{Introduction}

Indonesia is a state of law. The statement has clearly been stated in paragraph 3 of Article 1 as the result of the fourth amendment to the 1945 Constitution, abbreviated (UUD 1945), which said that "The State of Indonesia is a State." "Based on this declaration, all aspects of life in this country are regulated and limited by legal norms that apply in social, political, cultural, economic, and other fields.[1] Therefore, all human rights actions are regulated by law in the context of, Therefore, in actual community life, any problems that arise must be resolved following applicable law, but there are still many people in Indonesia who commit acts that are not under the local law.

Many laws protect the interests of the general public, including the codification of the Criminal Code, or commonly known as the Criminal Code. The Criminal Code is a law that contains regulations that apply in Indonesia, and one of the legal norms to protect the interests of the general public is social networking or where there are many cases of defamation: the result of humiliation in this way is character assassination. and human rights violations.[2] Cases of vilification are classified as computer crimes or computer crimes.

The Criminal Code regulates criminal acts of humiliation as regulated in Articles 310 to 321. Verbal and written insults through complaints of defamation, defamation, or insults are regulated in Articles 310 to 321 of the Criminal Code, and other legal provisions relating to defamation and defamation offenses that settled in Law Number 32 of 2002 concerning Broadcasting, Law No. 11 of 2008 concerning Information and Electronic Transactions, and various other sectoral or specific laws. Can replace the consequences of people who do slander.[3] Compensation for defamation is regulated in the Civil Code or commonly abbreviated in Articles 1372 to 1380 of the Civil Code as an unlawful act regulated in Article 1365. The types and methods of the crime itself continue to grow. On the other hand, the success rate of tracing perpetrators of defamation using information technology is still super- 
low. It is a significant concern for society as a whole. The harm caused by this crime is not minor. The development of defamation crimes is increasing to date, including technological developments that do not reduce crime but vice versa. The crimes committed are increasingly sophisticated and complex, not as simple as imagined. "Cyberspace as a new development in the history of human civilization makes it difficult to apply the law following applicable procedures (criminal justice system)."[4]

One of the criminal acts of defamation committed by abusing technological sophistication is manipulating with various intentional criminal acts that cause harm to someone, both tangible and intangible.[5] Defamation of a person can be carried out using software that is part of technological sophistication, so the delinquency contains elements of defamation of a person or an institution, such as cases of humiliation, accusations against victims who suffered heavy losses, both material as intangible. Based on the description above, this article will describe the criminal act of defamation in criminal law.

\section{Method}

This research is normative legal research[6] that examines the rule of law regarding defamation. This study only examines legal theories related to the regulation law and defamation cases in cyberspace. The data in this study is secondary data obtained from various books, journals, research reports, or news and incidents obtained both through print and online media.[7]

\section{Discussion}

Among the types of offenses in the Criminal Code, some types can only be prosecuted if there is a complaint from the aggrieved party. It is regulated in Chapter VII of the Criminal Code regarding the submission and withdrawal of complaints about the offense committed only prosecuted on complaints. The criminal act of defamation is one of the reported crimes. Defamation is defamation of someone by stating something orally or in writing. In vilification, there are three primary things, namely: "first, a lawsuit for defamation is a subjective lawsuit, second, defamation is a criminal act of dissemination, third, a person who commits defamation by accusing something." [8]

Based on this information, there are several important notes regarding this matter: A defamation lawsuit is a subjective lawsuit, meaning that the assessment of vilification depends on the party whose reputation has been defamed. For example, a pollution offense is a complaint offense that can only be handled by the competent authority if there is a complaint from a pollution victim. Slander is a spreading crime. These substances contain contaminants that the author released to society or the public. [9] A person who commits defamation by accusing something that examines to damage the reputation of another person or party must be allowed to prove the accusation. For the people of Indonesia, the article on slander is considered following the the nation's characters that upholds the customs and culture of the East.

On that basis, defamation is an act that examines a form of injustice before it is enshrined in the law because it violates the rules of decency. Moreover, insults and slander consider a violation of religious norms if the content of the slander contains slander. Moreover, this is 
regulated in the Criminal Code (KUHP) chapter XVI concerning Defamation Article 310 reads as follows[1]:

a. Anyone who assaults somebody's honor or notoriety by blaming somebody for something, the goal of which is clear so it is known to the general population, is compromised with criticism with a greatest detainment of nine months or a most extreme fine of 4,000 500 rupiahs.

b. If this is finished using composing or a transmission picture, shown, or glued out in the open, the danger of composed defamation is deserving of a greatest detainment of one year and four months or a most extreme fine is 4,000 and 500 rupiahs.

c. It doesn't comprise slander or composed attack if the demonstration is done in the public interest or in light of the fact that it is compelled to shield oneself.

Based on Article 310 of the Criminal Code and the Criminal Procedure Code above, it is clear that this activity regulates in law with definite sanctions. Therefore, to be charged with the defamation article, the elements of the defamation article must be met. If those elements are not present, no one can be charged with defamation. The extent to which an act is classified as defamation of others is still unclear because many factors must be considered. In the case of defamation or injury to be protected, everyone has to respect others from the point of view of their honor and reputation in the eyes of others.

Defamation can also be interpreted as the act of someone who intentionally defames or defame the good name or good name of that person, thus causing others to view badly of someone who was initially good and is known to many people as corrupt or not better in public. Defamation includes in the case of complaints of violations because someone who knows that his name has been slandered or defamed by other people's adverse treatment can sue in a civil court, and if the party who reports wins can sue and obtain compensation, then imprisonment can be imposed on the party who commits defamation.

Statements that contain information that is not factual and generally tend to embarrass someone and such affirmations that can harm that person are defamation. Slander is categorized into two main types such as; defamation is called defamation if the statement is not factual and can hurt someone, and the utterance is made in a permanent form, such as writing, radio or television news, rumors, is called gossip if the statement broadcast is not permanent, such as a conference/speech. Defamation in newspapers can usually lead to opposition from writers, editors, publishers, and distributors. Then the judge must also be able to ensure that the words used are slander or not.

The concept of defamation in criminal law regulated in the Criminal Code is based on two main reasons. First, the Criminal Code contains primary provisions that can be used as basic guidelines for criminal legislation preparation outside the Criminal Code. The aim is to create substantial unity in the criminal justice system and ensure harmonization. While the form of vilification is still under discussion, the provisions for defamation in Chapter XVI of the Criminal Code are still considered very relevant. The definition of humiliation is an act that damages a person's reputation and honor. Umar Seno Adji defines slander as "damage to honor or reputation (attacks of good name)." One form of slander is "..., slander in writing and done by accusing something, ...". Defamation appears from two types, namely verbal and written vilification. In his book, Umar Seno Adji states that slander is known as insults is divided into 'material insults and formal insults.' [9]

Material insults are offenses that consist of a fact that contains an objective statement orally or written so that the contents of the utterance, both written and oral, are decisive. It is still possible to prove that the allegations had made in the public interest. In the case of formal insults, in which the situation is not stating the content of the insult but how the statement in 
question is made. The form and method are the determining factors. In general, the way of expression is still rude and not objective. The possibility of proving the truth of the allegations does not exist, and we can say that the probability is closed. The object of the insult must be an individual human being, that is, not a government agency, administrator of an association, a group of residents, and others. Based on Article 310 paragraph (1) of the Criminal Code, insults that can be punished must be carried out by accusing someone of having committed a specific act, with the intention that the accusation will be broadcast (known to many people). The alleged act does not need to be an act that can be punished, such as stealing, embezzling, and adultery. These actions are ordinary actions, which are shameful acts, for example, alleging that someone has an affair. In this case, it is not an act that can be punished, but it is an embarrassing announcement for those concerned. The accusation must be verbally made, if it is made in writing (letters) or pictures, then the insult is called insulting by letter (in writing) and can be subject to Article 310 paragraph (2) of the Criminal Code.

Insults, as indicated by Article 310 sections (1) and (2) above, can be rejected (can't be rebuffed) if the allegations or affronts are made to guard the public interest or are compelled to protect themselves. Whether or not the safeguard of the public interest and the self-protection presented by the speculate lies in the appointed authority's thought. For the wrongdoing of defamation in accordance with Article 311 of the Criminal Code, it doesn't have to happen out in the open is adequate if it would demonstrate that there is an expectation to communicate the allegation. If the affront is as an objection containing smear that is coordinated to the specialists/authorities, then, at that point, it very well may be dependent upon criminal Article 317 of the Criminal Code. "Threats of defamation lurk," referring to Muladi's opinion, those who can report defamation.

\section{Conclusion}

The criminal act of defamation in Indonesian criminal law has regulated in Article 310 of the Criminal Code. Nonetheless, alongside the mechanical advances, how criminal demonstrations of criticism are progressively different. One of them is a demonstration of slander against somebody posted through different media. The components of Article 310 of the Criminal Code can't influence the offense of attack carried out by this demonstration to apply the rule of lex specialis derogat legi generalis. With this guideline, the standards of the Criminal Code can be renounced by utilizing more explicit guidelines overseeing all types of exercises in the internet, to be specific by using Article 27 passage 3 related to Article 45 section 1 of Law No. 11 of 2008 concerning data and electronic exchanges. Without a doubt, the creator's activities have entered the lawful field as directed in Law Number 11 of 2008 concerning Information and Electronic Transactions, in particular the web as a medium for carrying out his actions.

\section{References}

[1] M. Reksodiputro, Hak Asasi Manusia Dalam Sistem Peradilan Pidana [Human Rights in the Criminal Justice System.]. Jakarta: Justice and Legal Services Center (University of Indonesia), 1999.

[2] E. Hidayat, "Perlindungan Hak Asasi Manusia Dalam Negara Hukum Indonesia [Protection of Human Rights in the State of Indonesian Law]," Asas J. Huk. dan Ekon. 
Islam, vol. 8, no. 2, pp. 80-87, 2016, [Online]. Available: https://www.neliti.com/publications/56534/perlindungan-hak-asasi-manusia-dalamnegara-hukum-indonesia.

[3] R. Atmasasmita, The Criminal Justice System, Existentialism and Abolitionism Perspectives. Bandung: Bina Cipta, 2016.

[4] Widodo, Aspek Hukum Pidana Kejahatan Mayantara [Aspects of the Criminal Law of the Crime of Mayantara]. Yogyakarta: Aswaja Pressindo, 2013.

[5] Moeljatno, Azas-Azas Hukum Pidana [Principles of Criminal Law]. Jakarta: Bina Aksara, 1993.

[6] M. Abdul Kadir, “Law And Legal Research.," Bandung PT. Citra Aditya Bakti., 2015.

[7] I. M. P. Diantha, "Normative Legal Research Methodology," Teor. Metodol. Penelit. a., 2017.

[8] Supriyadi, "Penerapan Hukum Pidana Dalam Perkara Pencemaran Nama Baik [Application of Criminal Law in Defamation Cases]," Mimb. Huk., vol. 22, no. 1, 2010.

[9] H. Z. Wadjo, "Pencemaran Nama Baik Dalam Pemberitaan Pers [Defamation in the Press]," J. Sasi, vol. 17, no. 2, 2011. 